\title{
Buildings and constructions safety operation on karstic territories of the Samara city
}

\author{
Andrey Maltsev ${ }^{1,{ }^{*}, \text { Margarita } \text { Baranova }^{1} \text {, and Alla Ponomarenko }}{ }^{1}$ \\ ${ }^{1}$ Samara State Technical University,Institute of Architecture and Civil Engineering, 194, \\ Molodogvardeyskaya St., 443001, Samara, Russia
}

\begin{abstract}
During the last 20-25 years the geological structure of the city has considerably changed due to different anthropogenic and technological factors. The geotechnical situation of the Samara city needs to be specified. In the first place, it is about karstic territories that are under active maninduced impact. Water utilities leakage, snow melting and rainfalls cause carbonates soakage which results in carbonates damage and karst appearance accompanied by cavities in the earth shell of different size and shape. Karst changes the current eco and geological system - the natural landscape. These deformations are highly disadvantageous for buildings and constructions on karstic territories, as they can lead to serious circumstances - partial or full building failures. Besides, karst and suffosion have recently become more frequent, which directly endanger human safety and even life. This paper presents results of the analysis of karst and suffosion development on the territory of Samara. It observes geotechnical problems of using karstic grounds as structure bases, gives reasons for necessary geotechnical monitoring at the stage of examination, as well as reasons for implementation of anti-karstic engineering and technical measures during building erection and operation.
\end{abstract}

\section{Introduction}

Nowadays, more sites with difficult ground conditions, including karstic territories, are developed for constructionin Samara. Water utilities leakage, snow melting and rainfalls cause carbonates soakage which results in carbonates damage and karst appearance accompanied by cavities in the earth shell of different size and shape. Karst changes the current eco and geological system - the natural landscape. These deformations are highly disadvantageous for buildings and constructions on karstic territories, as they can lead to serious circumstances - partial or full building failures. Besides, karst and suffosion have recently become more frequent, which directly endanger human safety and even life. Thus, it is necessary to monitor the conditions and dynamics of karst appearance at the stage of examination, designing, erecting and maintenance of buildings, as well as to introduce effective anti-karsticmeasures.

${ }^{*}$ Corresponding author: geologof@yandex.ru 
The aim of this work is to assess the condition and dynamics of karst formation in Samara on the stages of research, design, construction and operation of buildings and to classify the most effective anti-karstic measures.

\section{Materials and Methods}

At the beginning of 90 s of the $20^{\text {th }}$ century, a map of unfavorable for building geological conditions appeared on the territory of the Samara city. The results of engineering examination analysis were introduced by the staff of the Department of Engineering Geology, Baselines and Foundations in the Institute of Architecture and Civil Engineering with the support of Kuibyshev Trust of Construction-Engineering Examination (Fig. 1). The map also included karstic areas of the city. During the last 20-25 years, the geological structure of the city has considerably changed due to different internal and external, primarily anthropogenic factors. The geotechnical situation of the Samara city needs to be specified.

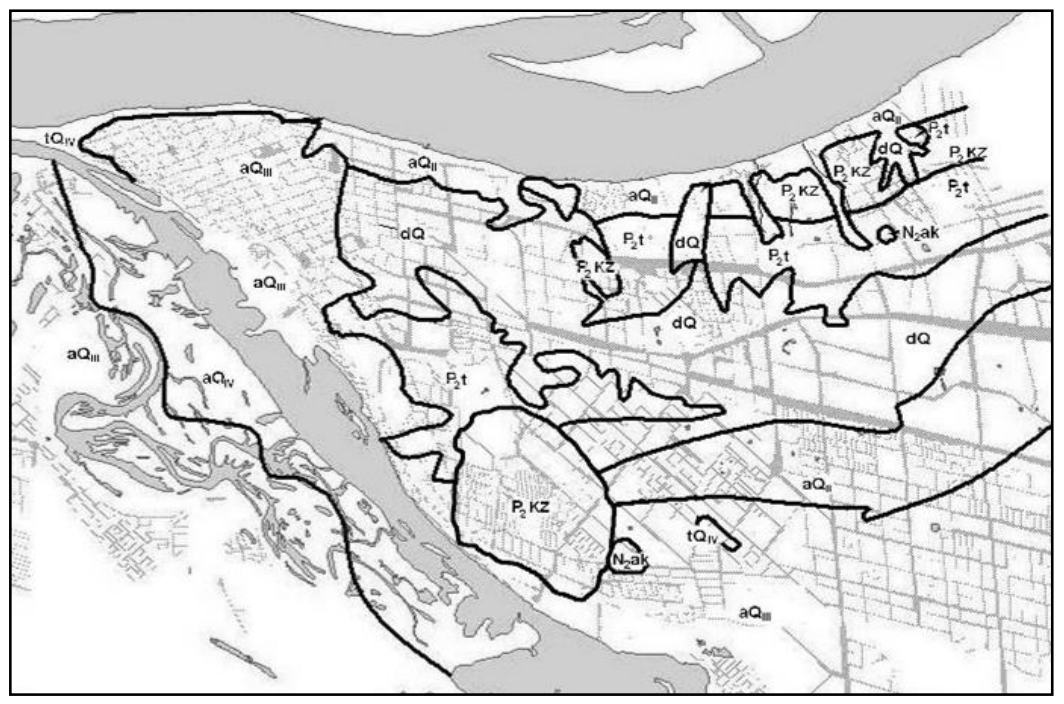

Fig. 1.The geological structure of Samara: sketch map.

This study covers the following tasks:

- it reveals characteristic features complicating the construction of buildings and structures in Samara at present;

- it specifies karst and karst processes negative impact on geotechnical properties of building foundations;

- it assess karst-suffosion processes state and growth on the territory of Samara;

- it gives analysis of materials illustrating failures of some construction projects in Samara;

- it reveals the most important causes of karst processes on the territory of Samara;

- it justifies the choice of the most effective engineering activities reducing risk of karstsuffosion processes formation and growth in buildings and structures foundations in Samara.

To achieve these results the researchers applied methods of scientific analysis and of factual material classification. 


\section{Results}

The analysis conducted by the authors showed that at present building construction in Samara is determined by the number of features [1].

One of them is a geotechnical situation. Almost all the sites with good structure bases are in use today in the Samara city. That is why new building process is forced to be introduced on the territories with unfavorable engineering and geological conditions with foundationson grounds prone to non-uniform deformation.

Geological condition of the Samara city is defined as extremely difficult and determined by difference in age, origin and geological structure of the solid,which results in development of dangerous geological processes such as underflooding, karst and suffosion, slides, sagging, etc., related tochanges in hydrogeologic situation.

In recent years, more sites are developed in high flood basins in water conservation districts, on the slopes on the banks of rivers Volga and Samara. It causes certain geotechnical and ecological problems and restrictions. The Article 65 of the Water Code of the Russian Federation [2] says that water conservation areas are territories adjacent to coastlines of seas, rivers, streams, canals, lakes, reservoirs where special regime of economical or other activity is set with purpose to prevent pollution, contamination, muddying of the mentioned water objects and depletion of their waters, and to save habitat of water biological resources and other objects of flora and fauna. Within their boundaries, designing, location, construction and reconstruction, putting to operation and maintenance of the economical or other structures are allowed on conditions that these constructions are equipped with facilities, providing water objects with protection from pollution, contamination and depletion of waters according to water laws in the region of environment protection[3].Within protected shoreline belts, along with the introduced restrictions for water conservation districts, the following activities are prohibited: land plowing; dumping spoil ground, cattle pasturage with summer camps and baths arranged. During building process, connected with stacking, damage of natural stratification can happen as the result of additional load on the slope. In such a case, slope stability can be disturbed which follows by the earth slide process. Beside slope processes, karst and suffosion activity of the sites can have a negative influence on new building as well as hotspot construction. It often results in non-uniform deformation of the erected buildings.

Another particularity is land shortage, i.e. lack of sites for new constructions. According to the General layout, development of the Samara city should undergo by means of internal territory reserves. One of the variants of the city territory development is to actively use the territory within the current urban district boundaries. This variant allows not to go beyond the boundaries of the present city infrastructure. The modern post-soviet period of the Samara city development was characterized by Samara architect V.G. Karkaryan as the total absence of any city-planning idea [4]. Indeed, buildings are introduced in a hotspot, hasty, random way and generally in central parts of the city. This results in the tendency of increasing the number of floors in a building and constructions, which increases the load on structure base. In addition, city urbanization leads to the necessity to construct underground facilities different in purpose, design planning, constructive nature; buildings go deep underground[5].

The third particularity is that the last $15-20$ years reconstruction and modernization of existing constructions take place more frequently, together with new building process. In this regard, building is often introduced in tight working space of ready built-up area of the city, which means close to existing buildings [6]. Reconstruction (redesign, add-on structures etc.), demolition of small, shabby dwellings with high-rise buildings erectioninstead also leads to higher load on structure base. In addition, the increase in city construction density and number of floors result in higher load on city utilities that have long been in need of major 
reconstruction and modernization. In most cases, man-caused leakages and additional pressure on structure base leads to deterioration of their qualities and as a result to partial or full building failures of separate structures or construction in general.

It should be noted that intensity and variety of human economic activities at the modern stage cause significant negative impact on the geological environment of variable types of man-caused influence. They activate old and bring about new dangerous geological processes. Thus, it is critical to assess the geological environment reaction to man-caused impacts and to define its stability.

The most pressing issue for the Samara city is the impact of karst and karstic processes on structure bases of buildings and constructions, the reason for it being construction growth in less favorable engineering and geological conditions and human economic activity. In last decades, karstic territories of the city started to be actively utilized.

The staff of the Department of Engineering Geology, Baselines and Foundations in the Institute of Architecture and Civil Engineering introduced a research at the end of 80sbeginning of 90 s of the XX century. The research showed that karstic solids occupy up to $70 \%$ of the Samara territory $[7,8]$. Karst seriously complicates building process and makes it more expensive. Thus, study of karst and its aspects has an important practical meaning. Karstic territories are the ones with water-soluble geological formations (limestone, dolomite, marlstone, chalk, plaster, anhydrite, mineral salt, etc.) and territories with existing or possible surface and (or) underground karst.

Analysis of archive data and engineer and geological research of the authors [1,7-8] of karstic territories of the Samara city in the last 20-25 years showed that karstic processes date back to ancient times and cover huge depths of Permian and coal formations. They are characterized [9] by solids with increased fracture zones and masses of decayed rock; favorable recharge hydrogeologic situation, underground water draining into cavities and fractures; existence (or lack) of covers for karstic formations with complicated lithography.

Karst and suffosion processes are widespread within the Samara city on slopes of the riversides Volga and Samara. Karst processes here are accompanied by ground wash away, suffosion, deformation of earth surface and construction structure bases, changes in qualities of ground covering formation, particular circulation and mode of underground and surface waters.

Type of rock bedding and terrain pattern of the ground features lowland karst with horizontal bedding. Karst can be characterized by its composition as carbonate (lime stone, dolomite, marl stone, chalk); carbonate-sulphate (lime stone, dolomite, plaster and anhydrite of Permian age); sulphate (plaster and anhydrite).

Carbonates within the territory of the Samara city are highly fractured and partly destroyed to earthly marl and dolomite powder. As the result of karst process, karst and suffosion sinkholes appear on the surface, gulleys. The areas with karst and suffosion process on the territory of the Samara city are situated generally on water-dividing plateau of the rivers Samara and Volga. Their geological structure is defined with Permian formation of the Tatarian Stage up to the depth of 50-70 m. On the surface, they are covered with Quarternary protective formation with different depths in the form of alluvial and eluvial-deluvial formations and spread almost everywhere. They are mostly clays and sandy clays, less often clay sands and sands. Below are Permian formations of the Tatarian Stage, spread over the Permian formations of the Kazanian Stage.

In the majority, the abovementioned grounds are solid structure bases for buildings and constructions, but they have a number of disadvantages. First of all, it is Permian formation clay watering and their marl quality. Marl stones are different in proportions of clay, silt and sand particles and always contain calcite. Some types of them quickly and instantly swell in water during soaking. The process is accompanied by suffusion particles removal with water trickles into cavities that appear around and underneath. Water leakage in water and sewerage systems, heat traces go high-scale in some cases and lead to extra- 
moisturized ground. There is a danger of near complete wash away of ground particles from their resting place. Consequently, such sites could be reasonably supposed as zones with serious possibility of karst-suffusion breakdown.

In general, sinks represent the greatest threat to the stability of buildings and structures in karstic areas because of the suddenness of their occurrence. Sinks are forming at a depth for a long period of time, whereas on the surface the breakdown process passes very quickly. A weakened zone is noted around the breakdowns, which reduced load-bearing capacity of soil, cracks and slight surface subsidence. Gradual subsidence of the earth's surface, resulting, for example, from undermining the territory or global change of groundwater levels, presents relatively low risk compared with the sinks.

In the recent years, due to the dry summer-spring period, the occurrence of karstsuffusion processes, that threaten the security and even human life, became more frequent. For example, a sink, having an oval shape in terms of the maximum diameter of $7.8 \mathrm{~m}$ and a tapered shape in cross-section with the depth of approximately $13 \mathrm{~m}$, was detected during the examination of construction projects on the sites of Samara slope on the street Maloyaroslavskaya in the Zheleznodorozhny district of the city [9]. Estimated volume of dissolved and groundwater-borne rocks was about $800 \mathrm{~m}^{3}$. According to the results of research conducted at the neighboring sites, it was determined that all of the surrounding area was full of karst sinkholes. Thus, the integrity of the active base zone destroys and breaks gradually but progressively over time, which leads to unacceptable deformations of buildings and, possibly, to a complete failure. Figure 2 shows a well-known house in the city of Samara, located on the Aurora Street in the Zheleznodorozhny district. The house is in a critical condition, and progressive deformation has been continuing for several years. In March 2016, the ground next to the specified house broke down and formed a pit with a diameter of $6 \mathrm{~m}$ and a depth of $10 \mathrm{~m}$.

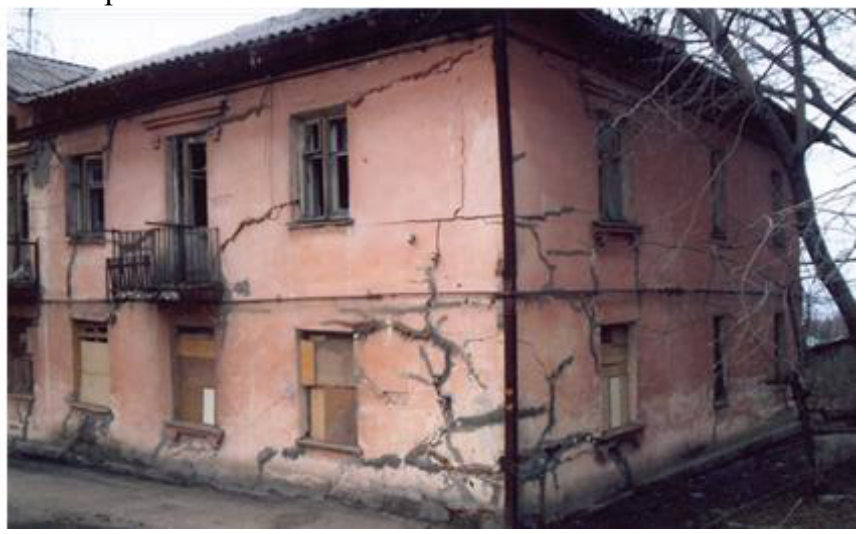

Fig. 2. Residential house. Samara, Zheleznodorozhny district, 20 Aurora Street

Analysis of the geotechnical material suggests that there has recently been the activation of karst and pseudo-karst in many areas of the city due to man-made processes.

Intensive construction and anthropogenic activities have increased direct and indirect effects on the geosphere, which led to significant reduction in the strength and deformation properties of the soil at the base of buildings and structures.

There is still a serious problem to regulate atmospheric discharge, sewage and flood water, unacceptable leakage of liquids from pipelines and canals. Figures 3 and 4 show the photographic evidence of the roadway breaks as a result of heating main burst on Lenin Avenue in the Octyabrsky district of Samara, which took place in 2011 and 2016 
respectively. The first incident of August 23, 2011, took the life of the driver whose car fell down. In the second case, on October 18, 2016, the breakdown area was about $15 \mathrm{~m}^{2}$. Two cars fell into the resulting hole.
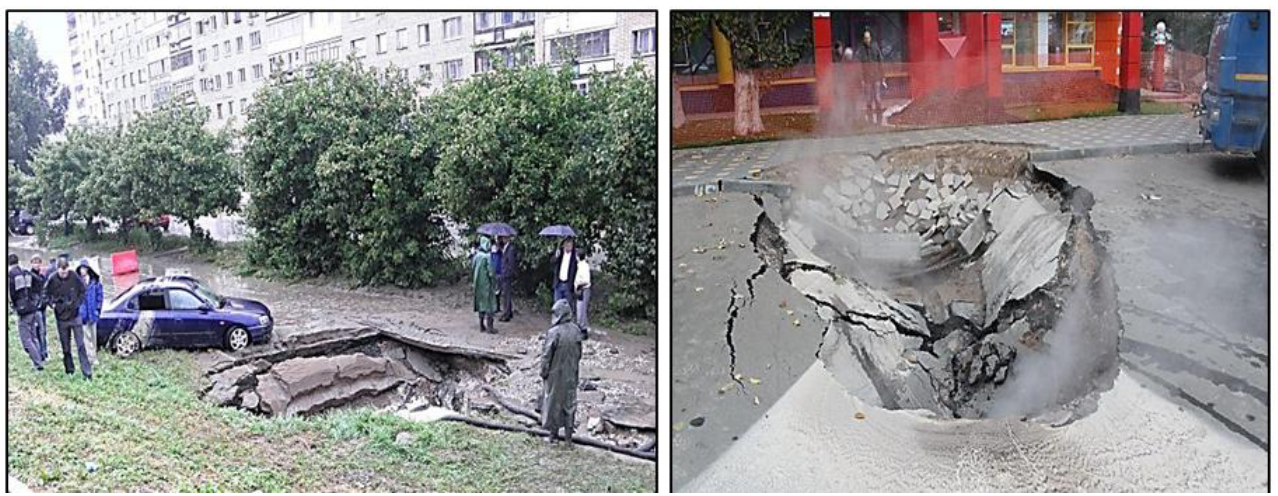

Fig. 3. Sinkhole on Lenin Avenue, 23.08.2011. Fig. 4. Sinkhole on Lenin Avenue, 18.10.2016.

\section{Discussion}

Engineering and construction development of the karstic territories must be based on objective assessment of karst danger to make a decision about the development of these territories and foresee the likelihood of accidents and disasters. This problem can be solved through scientifically-based geotechnical monitoring at the stage of pre-construction research and anti-karst engineering technical activities during construction and operation of buildings and structures.

In the current situation, in the absence of a complete picture of the present geological situation, it is necessary to conduct geological and hydrogeological monitoring throughout the whole territory of Samara, which will make it possible to predict the behavior and changes in karstic grounds in the base of structures under the influence of various factors. In the first place, we should identify areas of karstic rocks spread and areas of actual or potential activation of karst processes, as well as natural and man-made sources of soakage. Observations can be carried out with all available resources. It is advisable, for example, to combine the drilling of exploration wells with GPR investigations using ground-penetrating radars. This drilling will directly determine the strength and nature of the soil strata, the level and direction of groundwater; it will detect karst cavities and take samples to determine the parameters of their physical and mechanical properties. GPR research will help outline the picture of the spread of cavities in the built-up and operating areas, and identify the sources of man-made water leaks from the mechanical, electrical and plumbing networks. The creation of special geotechnical monitoring service in Samara is necessary to gather information on research and its analysis; the aim is to develop an actual unified information geotechnical base for construction.

During the period of construction and operation of buildings and structures on karstic territories, it is necessary to eliminate all the factors that lead to soakage sources and increase the permeability of karst rocks. Engineering and technical measures to reduce the risk of development and karst-suffusion processes include the following[1, 10-11]:

- Decreasing the load of structures on the base. In the given soil conditions, it is reasonable to build low-rise building on the foundations that can redistribute the load on the base more evenly (slab, cross-belt). The horizontal and vertical layout of the buildings should be rational. Construction of the "heavy" buildings, infill development and 
considerable uneven load on the foundation may lead to increased fracturing in karstic rocks;

- Using the methods of foundations installation that donot have any dynamic effect on the soils of the base, for example, impact methods. First of all, this refers to piling, using foundations in tamped foundation pits, creating artificial bases with tamping, etc. Impact load in this case can also enhance fracturing and, consequently, the permeability of karsted rock;

- Using "dry" technology in the construction of the underground part and of the whole building;

- Not allowing soil soakage of the base during the construction of the zero cycle; protecting the foundation pits of buildings and trenches for mechanical, electrical and plumbing networks from flooding;

- Taking waterproofing measures on construction sites. This is achieved by the rational layout of the master plan; vertical layout of the territory, which provides runoff of surface waters; drainage devices, watertight diaphragm and screens;

- Continuous monitoring of the technical condition and immediate repair in case of damaging protective blind areas around buildings, asphalt pavements and roads;

- Laying water communications in special channels; constant control of the equipment technical condition and possible leakages of water supply and sewerage systems (for example, using ground penetrating radar); maintaining the city storm water sewage in good operating condition.

According to the academician F.P. Savarenskii et. al. [12-15], adverse geological conditions are not so much dangerous during the construction of engineering structures, as are lack of knowledge of the conditions and the inability to evaluate them in terms of a particular engineering measure. In this case, this statement can be fully attributed to the construction in the karstic areas in Samara.

\section{Conclusions}

1. Building construction conditions on the karst territories of Samara should be described as complicated. Karst processes affect the properties of buildings and other structures foundations.

2. To improve the quality of construction products and extend their service life, geotechnical investigations must be carried out accurately and fully according to current regulations; buildings and facilities must be erected and maintained professionally and competently. Non-compliance with these requirements may result in failure of the "basebuilding" system and, as a consequence, in significant material losses and threat to human safety.

3. Following the recent government documents for the construction industry, it is important to note the current guidelines for construction in the fields of engineering survey, design, construction and operation, which ensure the reliability and safety of buildings and structures. They include the following:

- Scientific support at the stages of engineering survey, design, construction and operation of the building objects;

- Geo-monitoring of environmental components in the construction area;

- Monitoring the technical state of the building base, construction structures and systems of engineering support during construction and operation of a building or structure;

- Monitoring the status of adjacent buildings and structures within the area of influence of the building object during its construction and operation. 


\section{Acknowledgments}

The authors express their gratitude to the colleagues from the Department of geological and foundation engineering of the Samara State University of Architecture and Civil Engineering - Professor, actual member of New York Academy of Sciences, Vadim P. Kostuk, Professor Gennady A. Druzhinin, Associate Professor Nina B. Chechina, Associate Professor Olga M. Kakutina, Associate Professor Daria I. Vasilyeva - for invaluable help in collecting material for this study.

\section{References}

1. A.V. Maltsev, M.N. Baranova, O.M. Kakutina, Samara building, 6 (75), 42-45 (2008)

2. $\quad$ Federal Law 74, Water Code of the Russian Federation (2006)

3. A.K. Strelkov, M.A. Gridneva, T.Yu. Nabok, E.V. Dremina, E.E. Kondrina, Urban Construction and Architecture, 4, 55-62 (2014)

4. V.G. Karkaryan, The Volga River - the City of Samara: Journey through the Ages (Samara, Agni, 2011)

5. V.P. Generalov, E.M. Generalova, Urban Construction and Architecture, 1, 13-18 (2015)

6. A. Gnilomedov, Urban Construction and Architecture, 2, 16-20 (2014)

7. O.M. Kakutina, Multivolume collective monograph, V. 8, 117-129 (Samara, Samara State University, 2011)

8. M.N. Baranova, D.I. Vasilyeva, Geological and Geomorphological Zoning of Samara City (Germany, Saarbrücken, LAP LAMBERT, 2015)

9. O.M. Kakutina, Bulletin of Samara State University, 1, 95-99 (2011)

10. Design and Construction Specifications 47.13330.2012, Engineering Surveys for Construction. The Main Provisions (2012)

11. Federal Law 384, Technical Regulation on Safety of Buildings and Structures (2009)

12. L.V. Peredelsky, O.E. Prikhodchenko, Engineering Geology (Rostov-on-Don, Phoenix, 2006)

13. R. Usmanov, M. Rakočević, V. Murgul, N. Vatin, Applied Mechanics and Materials, 633-634, 927-931 (2014)

14. R. Usmanov, I. Mrdak, N. Vatin, V. Murgul, Applied Mechanics and Materials, 633-634, 932-935 (2014)

15. I Mrdak, M. Rakočević, L. Žugić, R. Usmanov, V. Murgul, N. Vatin, Applied Mechanics and Materials, 633-634, 1069-1076 (2014) 